\title{
Liofil és liofób kolloid diszperziók elektromos felületi tulajdonságai: a liotróp sorok érvényessége* 2. Elektromos felületi vezetés
}

\author{
MÉSZÁROS Renáta ${ }^{\mathrm{a}}$, MANILO Maryna ${ }^{\mathrm{a}, \mathrm{b}}$, LEBOVKA Nyikoláj és BÁRÁNY Sándora,c,d \\ a Alkalmazott Földtudományi Kutatóintézet, Miskolci Egyetem, 3515 Miskolc-Egyetemváros, Magyaroszág, \\ ${ }^{b}$ Biokolloidok Kémiája Kutatóintézet, Ukrán TA, Vernadszkij sugárút 42, Kijev, Ukrajna, \\ ${ }^{c}$ MTA-ME Anyagtudományi Kutatócsoport,3515 Miskolc, Egyetemváros, Magyarország \\ ${ }^{d}$ Kémiai Intézet, Miskolci Egyetem, 3515 Miskolc-Egyetemváros, Magyarország
}

\begin{abstract}
Bevezetés
Jelen publikációinkban, irodalmi adatok és saját kutatási eredmények alapján, a liotróp sorban elhelyezett ellenionok, különböző természetü, illetve különböző hidratáltsággal rendelkező részecskék elektromos felületi tulajdonságaira kifejtett hatását tárgyaljuk.
\end{abstract}

Az előző tanulmányunkban (lásd a jelen cikksorozatunk I. részét) részletesen vizsgáltuk alkálifém kloridok és szulfátok növekvő töménységü oldatainak hatását liofób (szulfo- vagy karboxil felületi csoportokat tartalmazó latexek) és liofil (aeroszil, cirkónium dioxid, Na-bentonit és laponit szintetizált mesterséges agyagásvány) kolloidrészecskék

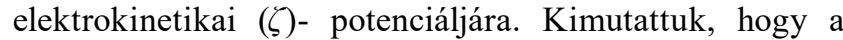
liofób kolloidok $\zeta$ - potenciáljának változása széles elektrolit-koncentráció tartományban $\left(10^{-5}-10^{-1} \mathrm{M}\right)$, illetve a liofil részecskék potenciáljának változásai tömény sóoldatokban $\left(10^{-2}-10^{-1} \mathrm{M}\right)$ követi az egyenes Hofmeister sort, azaz a $\mathrm{Li}^{+}<\mathrm{Na}^{+}<\mathrm{K}^{+}<\mathrm{Rb}^{+}<\mathrm{Cs}^{+}$sorrendben az ionok növekvő mértékben csökkentik a $\zeta$-potenciál értékét. Liofil részecskék $\zeta$ - potenciálja híg alkálifém klorid oldatokban $\left(10^{-4}-10^{-3} \mathrm{M}\right)$ a fordított liótróp sor követelménye szerint változik, azaz $\mathrm{Li}^{+}$tól $\mathrm{Cs}^{+}$felé haladva egyre nagyobb értéket mutat. Minden esetben a ,ک- potenciál- elektrolit-koncentráció” függvények maximumot mutató görbék szerint futottak le. A megfigyelt törvényszerüségeket az elektromos kettősréteg (EKR) zsugorodásával (jelentős ionerősségeknél), az EKR elektromos térben bekövetkező deformációjával és gerjesztett dipólus momentum megjelenésével (kis só-tartalmaknál), illetve az ellenionok $\mathrm{Li}^{+}$-tól $\mathrm{Cs}^{+}$-felé haladó sorrendjében, a Sternrétegben növekvő halmozódásával magyaráztuk.

Hasznos tájékoztatást nyerhetünk az EKR szerkezetéröl, az ionoknak a rétegben való eloszlásáról és mobilitásáról szuszpenziók elektromos vezetése mérések alapján. Az általánosan elfogadott elméleti elképzelések röviden az alábbiakban foglalhatók össze.
$K m$ vezetéssel rendelkező közegben $K p$ vezetésű tetszőleges formájú és orientációjú részecskékből álló- szuszpenziók $K p / K m$ relatív vezetésének expanzióját az általánosított Maxwell modell az alábbi összefüggéssel írja le1:

$$
\frac{K_{P}}{K_{m}}=1+[\sigma] p+O\left(p^{2}\right)
$$

(1), ahol $[\sigma]$ a határ-vezetőképesség és $p$ a részecskék térfogati törtje.

$\mathrm{Az}[\sigma]$ értéke függ a részecskék és közeg vezetésének $\Delta=\mathrm{Kp} /$ $\mathrm{Km}$, arányától, a részecskék formájától és az anizotróp részecskék külső elektromos térben felvett orientációjától. Tetszőleges eloszlású gömb alakú izolált részecskék esetében: $[\sigma]=3(\Delta-1) /(\Delta+2)$. Jól vezető közegben szuszpendált izolált részecskékre, amikor $\Delta<<1, \mathrm{a}[\sigma]=-1.5$ határérték érvényes, míg az ellentétes, $\Delta \gg>1$ határesetben: $[\sigma]=3$. Ez a p értékkel csökkenő $(\Delta<<1)$ vagy növekvő $(\Delta>>1)$ szuszpenzió-vezetöképesség rezsimnek felel meg.

Elektrolit oldatokban a kettősréteg polarizációja megváltoztatja a $[\sigma]$ értékét. Külső elektromos térben a részecskék ionfelhője deformálódik, polarizálódik, ami dipólus momentumot hoz létre ${ }^{2,3,4}$. Az indukált dipólus momentum nagysága egyenesen arányos a térerősséggel és a részecskesugár harmadik hatványával ${ }^{2,3,4}$. A felületi vezetőképesség koncepcióján alapuló elmélet az alábbi összefüggést adja meg relatív vezetés, a felület és oldat paraméterei között ${ }^{2,3}$ :

$$
\frac{K_{P}}{K_{m}}=1-1,5 p\left(1-\frac{3 D u}{(1+D u)}\right)
$$

Itt: $D u=K_{s} /\left(a K_{m}\right)$, ahol $D u$ az úgynevezett Dukhin szám (Lyklema terminológiáját követve ${ }^{5}$ ), $K_{s}-$ a fajlagos felületi vezetőképesség, ami nem más, mint az EKR-ben lokalizált ionok által létrehozott többlet-vezetés a tömbfázis vezetéséhez képest, és $a-$ a részecskék sugara. Izolált részecskék esetében $D u<<1$ feltételnél, az EKR polarizációja elhanyagolható és $[\sigma]=-1.5$ ("izolált" rezsim ), míg ellentétes $(D u \gg>1)$ határesetben $[\sigma]=3$ (szupravezető rezsim). A Kp/ $K m(p)$ függvények pozitív hajlásszögei a szupravezetés re-

\footnotetext{
Prof. Dr. Bárány Sándor: akmbsab@uni-miskolc.hu
} 
zsimben a felületi vezetés jelentős hozzájárulását tükrözi a szuszpenzió vezetéséhez, köszönhetően a kettősréteg fejlett ion-atmoszférájának. A felületi vezetést az EKR teljes diffúz részében fellelhető ionok koncentrációja határozza meg, függetlenül attól, hogy képződött-e a felületen vagy sem hidrodinamikailag immobil vízréteg. Tudvalevő, hogy az ebben a rétegben lokalizált ionok megtartják jelentékeny, a tömbfázisban lévő ionokhoz hasonló vezetőképességüket $^{3,6,7}$. Ennek következtében a felületi vezetés értékekből meghatározható a felület Stern-potenciáljának értéke $e^{2,3,4,5}$ (lásd még alább).

Kevés irodalmi adat áll rendelkezésünkre a Hofmeister sorok hatásáról diszperziók elektromos vezetésére. Lyklema híres monográfiájában ${ }^{5}$ egjegyezi, hogy nincsenek szisztematikus adatok a liotróp sorokban elhelyezkedő ionok hatásáról a felületi vezetőképességre, holott ez a legdirektebb módszer a jelenség vizsgálatára. Az egyik szerző korábbi dolgozataiban találhatók szórványos adatok néhány alkálifém só hatásáról polisztirol és cirkónium dioxid részecskék felületi vezetésére ${ }^{7,8}$. Jelen munkákban ezeket kiegészítettük a teljes alkálifém sor hatásának rendszeres vizsgálataival mind az említett diszperziók, mind karboxil-latex, aeroszil, bentonit és laponit részecskék vonatkozásában

\section{Anyagok és módszerek.}

Az előző cikkünkben ismertettük az általunk használt liofób és liofil részecskék előállításának módozatait, valamint a részecskék felületi töltésére, elektrokinetikai potenciájára, illetve ezeknek a pH és alkálifém kloridok és szulfátok hatására bekövetkezett változásaira vonatkozó eredményeinket. Alább ismertetjük a vizsgált részecskék felületi vezetőképességével kapcsolatos méréseink eredményeit.

A szuszpenziók elektromos vezetését OK 102/1 típusú konduktométer segítségével mértük $3 \mathrm{kHz}$-frekvenciás áram alkalmazásával (Radelkis, Magyarország). Ez a frekvencia lényegesen kisebb, mint a kettősréteg külső elektromos térben megvalósuló polarizációjának kritikus frekvenciája (néhány tíz vagy száz kHz) ${ }^{2,3,4}$.

\section{Eredmények és értékelésük}

\subsection{Alkálifém sók hatása}

A kapott eredmények illusztrációjaként az 1-3 ábrák bemutatják polisztirol, cirkónium dioxid és bentonit részecskék szuszpenziói relatív elektromos vezetésének változását a szilárd fázis térfogati törtjének függvényében állandó töménységü alkálifém kloridok oldataiban.

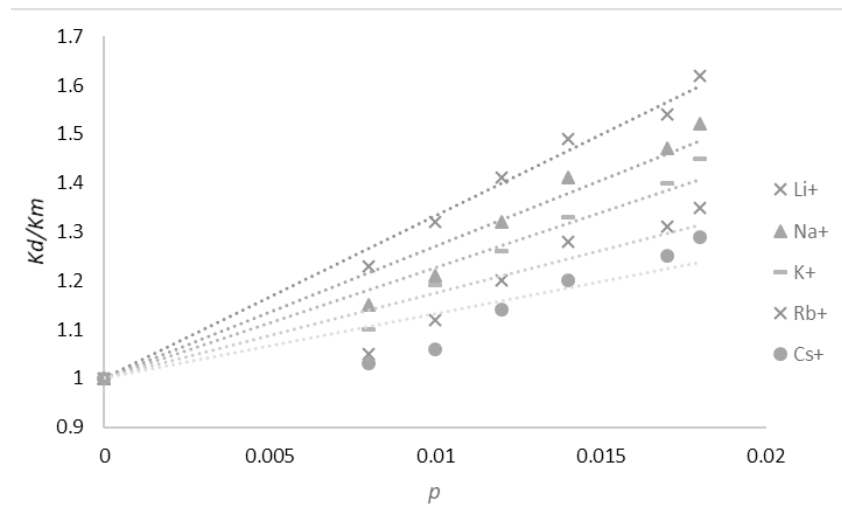

1. ábra. $\mathrm{PS}-\mathrm{SO}_{3} \mathrm{H}$ szuszpenzió $K d / K m$ relatív vezetése a részecskék $p$ térfogati törtjének függvényében $10^{-4} \mathrm{M}$ alkálifém klorid oldatok jelenlétében

Az 1. ábra szulfo-csoportokkal funkcionalizált polisztirol latex $\mathrm{Kd} / \mathrm{Km}$ ( $p$ ) függvényeit mutatják be $10^{-4} \mathrm{M}$ alkálifém klorid oldatokban. A liofób felületen legjobban adszorbeálódó $\mathrm{Cs}^{+}$ionok kivételével a függvények hajlásszögei pozitívak, ami az EKR ionjainak a szuszpenzió vezetéshez való jelentős hozzájárulására utal. A függvények hajlásszögével jellemezhető felületi vezetés értéke a $\mathrm{Li}^{+}$-tól $\mathrm{Cs}^{+}$felé haladva fokozatosan csökken, azaz egyenes Hofmeister sornak felel meg.

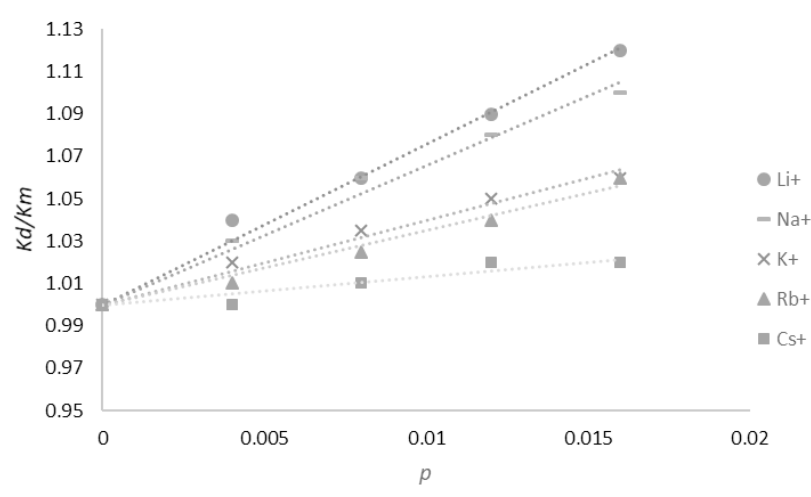

2. ábra. $\mathrm{ZrO}_{2}$ szuszpenzió $\mathrm{Kd} / \mathrm{Km}$ relatív vezetése a részecskék p térfogati törtjének függvényében $10^{-4} \mathrm{M}$ alkálifém klorid oldatok jelenlétében

A fentiekhez hasonlóan liofil $\mathrm{ZrO}_{2}$ szuszpenziók relatív vezetőképessége, változatlan só-koncentrációnál, a liotróp sorban $\mathrm{Li}^{+}$-tól $\mathrm{Cs}^{+}$-ig fokozatosan csökken (2. ábra). Ez azt jelenti, hogy a felület liofób/liofil jellege nem befolyásolja lényegesen az alkálifém ionok eloszlását az elektromos kettősréteg különböző részeiben. Ebből továbbá az a következtetés vonható le, hogy a megfigyelt eloszlást elsősorban az ionoknak a felülethez való elektrosztatikus vonzása határozza meg. 


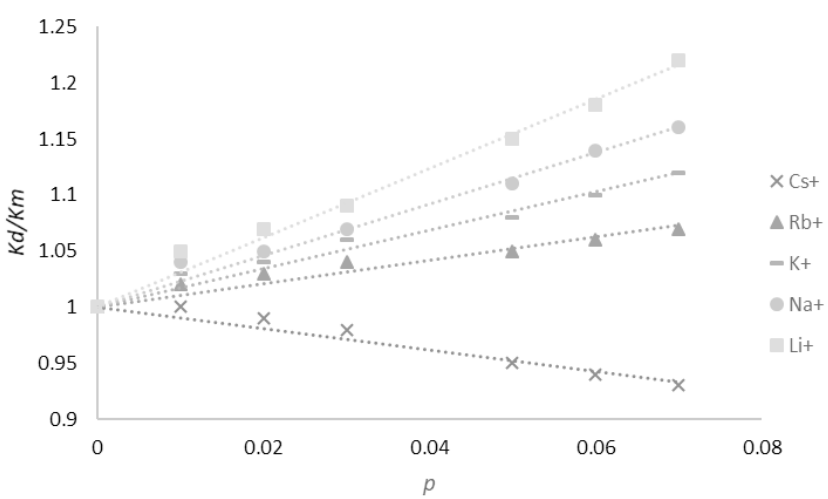

3. ábra. Na-bentonit szuszpenzió $K d / K m$ relativ vezetése a részecskék p térfogati törtjének függvényében $10^{-4} \mathrm{M}$ alkálifém klorid oldatok jelenlétében

A 3.ábra a Na-bentonit $K d / K m(p)$ függvényeit mutatja be állandó koncentrációjú alkálifém klorid oldatokban. Ebben a rendszerben is megfigyelhető a $K d / K m$ relatív (és ennek megfelelően a felületi) vezetés fokozatos csökkenése a $\mathrm{Li}^{+}$ -tól $\mathrm{Cs}^{+}$felé haladva, azaz a direkt Hofmeister sor helytállósága. A többi vizsgált rendszerhez képest abban mutatkozik eltérés, hogy a bentonit szuszpenzió esetében a $\mathrm{KCl}$ és $\mathrm{RbCl}$ oldatokban mért $K d / K m(p)$ függvények gyakorlatilag egybeesnek. Ez azt jelenti, hogy a $\mathrm{K}^{+}$ion nagyobb mértékben csökkenti a felületi vezetést, mint a liotróp sorban elfoglalt helyéből ez várható. Összhangban a bentonit részecskék $\zeta$ potenciáljára kifejtett hatással (lásd előző közleményünket), ez a megfigyelés is a $\mathrm{K}^{+}$ionoknak az ásványfelület iránti jelentős affinitásának a bizonysága.

\subsection{Az elektrolit-koncentráció hatása}

Az elektrolitok koncentrációjának hatását liofób (polisztirol) és liofil (Na-bentonit) szuszpenziók vezetőképességére a 4. és 5. ábrák mutatják be. Mindkét szuszpenzió hasonló viselkedést mutat.

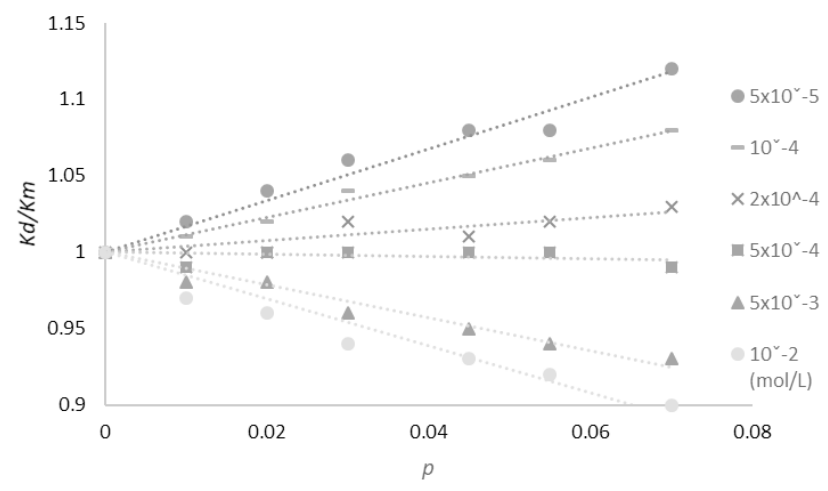

4. ábra.Szulfo-.csoportokkal funkcionalizált polisztirol latex szuszpenziók relatív vezetése a részecskék térfogati törtjének függvényében különböző koncentrációjú $\mathrm{KCl}$ jelenlétében

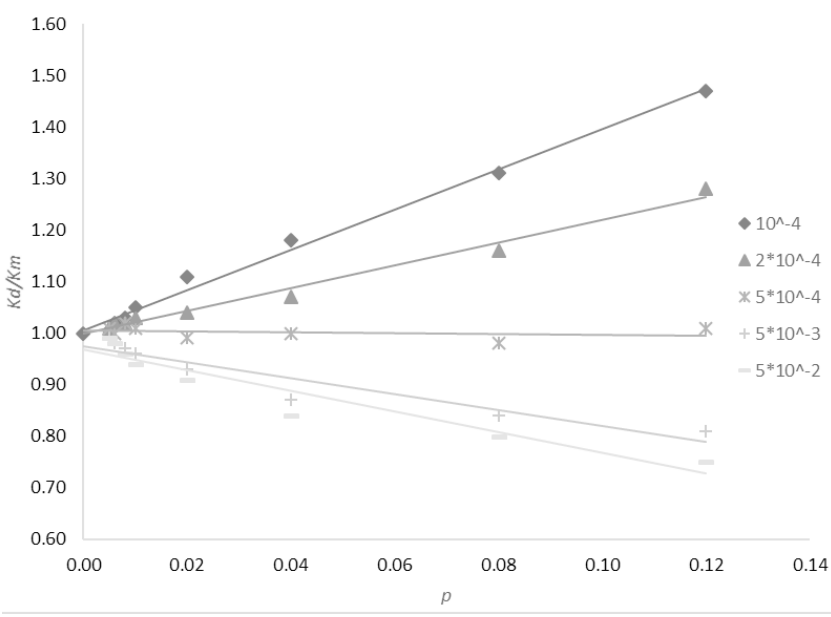

5. ábra. Na- bentonit szuszpenzió $K d / K m$ relatív vezetése a részecskék $p$ térfogati törtjének függvényében különböző $\mathrm{NaCl}$ koncentrációknál (feltüntetve az ábrán)

A szuszpenziók relatív vezetésének változása a részecskék térfogati törtjének függvényében lineáris összefüggést mutat, a függvények lefutásának hajlásszöge az elektrolit-koncentráció növekedésével csökken. Hasonló viselkedést mutatott számos különböző természetü szuszpenzió vezetése $\mathrm{e}^{2,3,4,8,9,10}$. Mint említettük, a pozitív hajlásszögű görbék a közegnél magasabb vezetéssel rendelkezö szuszpenziót jellemeznek, köszönhetően a fejlett diffúz kettősréteg hozzájárulásának a rendszer vezetéséhez kis $\mathrm{NaCl}$ koncentrációk esetében. Az x- tengellyel csaknem párhuzamos görbe az ún. izo- polarizációs állapotnak felel meg, amelyben a felületi vezetés hozzájárulása kompenzálja a részecskék jelenléte által okozott $K m$ csökkenést. A $K d / K m(p)$ függvények negatív hajlásszöge az elektrolit tartalommal növekszik az EKR zsugorodása és a közeg vezetésének jelentős emelkedésének következtében. Egy határ-koncentráció elérése után $\left(10^{-2} \mathrm{M} \mathrm{KCl}\right.$ a polisztirol szuszpenzióknál és $5.10^{-3} \mathrm{M} \mathrm{NaCl}$ a Na-bentonit szuszpenzióban) az elektrolit koncentráció további növelése nem emeli a görbék negatív hajlásszögét. Ugyanakkor a görbék kezdeti szakaszai negatív hajlásszögének határértéke nem haladta meg -3/2-t, ami a fent leírt elmélet érvényességére utal.

Általános esetben a fajlagos felületi vezetés a Stern és diffúz rétegekben lokalizált ellenionok koncentrációja $(\sigma)$ és mobilitása $(\mu)$ szorzatának összege ${ }^{4}$ :

$$
K_{s}=\sigma_{S t} \mu_{S t}+\sigma_{S t} \mu_{d}
$$

Feltételezhetö, hogy $\mu_{S t}<<\mu_{d}$ figyelembe véve a felület közeli erös elektrosztatikus és nem elektrosztatikus kölcsönhatásokat, valamint a közeg megnövekedett viszkózus ellenállását az ionok vándorlásával szemben. Ez azt jelenti, hogy a Stern-rétegben elhelyezkedő ionok hozzájárulása a felületi vezetéshez lényegtelen (de nem nulla ${ }^{11,12}$ ). Tehát, a liotróp sorban, a lítium iontól cézium ionig megfigyelt felületi vezetés csökkenés a Stern-réteg ebben a sorban történő növekvő telitettségének jele. 
Nemvezető gömb alakú részecskéket tartalmazó szuszpenzió $K d / K m$ relatív vezetésének függését a diszpergált fázis $p$ térfogati törtjének tartalmától a Duhin-Derjaguin- féle elmélet adja meg $^{2,3}$ :

$$
\begin{gathered}
\frac{\bar{K}_{d}}{K_{m}}=1+3 p\left[-\frac{1}{2}+\frac{3}{2}\left\{\frac{\text { Rel }}{(1+2 R e l)}\right\}\right] \\
R e l=D u=\frac{K_{S}}{K a}=\frac{\exp \left(\left(\frac{\bar{\psi} \delta}{2}\right)-1\right)}{\kappa a}
\end{gathered}
$$

ahol: $\mathrm{K}_{\mathrm{S}}$ - a részecskék fajlagos felületi vezetőképessége, a -részecskesugár, $\kappa$ - a reciproka Debye sugár, $\psi_{\delta}$ - a dimenziónélküli Stern-potenciál:

$$
\bar{\psi}_{\delta}=z e \frac{\psi_{\delta}}{k T}
$$

Az elmélet nem aggregált részecskék esetére és az EKR külső elektromos térben bekövetkező polarizációját is figyelembe véve lett kifejlesztve. A Duhin és Derjaguin által bevezetett dimenziónélküli $R e l$ kritérium ( $D u$ szám) jellemezi az EKR polarizációjának hatását az elektromos felületi jelenségekre. Ha Rel $(D u)<<1$, akkor a kettősréteg polarizációja elhanyagolható, ha pedig $\operatorname{Rel}(D u)>>1$, akkor a polarizáció figyelembevétele kötelezö.

Kísérleteink körülményei között a $K d / K m(p)$ görbék pozitív értékeinél az $\kappa a$ szorzat nagysága néhány vagy néhány tíz egységet tett ki, míg a számított $D u$ szám értékei polisztirol részecskéknél 0,14 és 7,0 míg Na-bentonit esetében pedig 0,06 és 1,7 között mozogtak. Ez azt jelenti, hogy a $\zeta$ - potenciál számításánál az EKR polarizációja, első megközelítésként, elhanyagolható. A felületi vezetés adatokból meghatározott $D u$ szám alapján kiszámítottuk a részecskefelület Stern $(\psi \delta)$ - potenciál értékeit (1. fenti egyenletet), amelyek széles elektrolit-koncentráció tartományban $\left(10^{-5}-10^{-2} \mathrm{M}\right.$ $\mathrm{KCl})$ a kísérletileg mért $\zeta$ - potenciál értékek többszörösének bizonyultak (részletesebben lásd ${ }^{4,8,9}$ ). Ebböl továbbá az a következtetés vonható le, hogy a vizsgált részecskék felületén aránylag vastag hidrodinamikailag immobil vízréteg képződik, amelyben az ionok megtartják jelentős mozgékonyságukat.

A liofil és liofób részecskéket tartalmazó szuszpenziók relatív vezetésének viselkedése demonstrálja az elektromos kettősréteg polarizációja (felületi vezetőképesség) hatásának csökkenését a Hofmeister sorban a $\mathrm{Li}^{+}$-tól a $\mathrm{Cs}^{+}$felé haladva. A részecskék elektromos térben megfigyelt viselkedése, azaz mind az elektrokinetikai potenciál, mind a felületi vezetőképesség változásai a liotróp sorban korrelálnak az alkálifém ellenionok sugarának, mozgékonyságának változásaival. Ezek a változások jól magyarázhatók az alkálifém ionok különböző eloszlásával az elektromos kettősréteg diffúz és tömör (Stern) rétegében.

\section{Köszönetnyilvánítás}

A kutatómunka a Miskolci Egyetemen müködő Alkalmazott Földtudományi Kutatóintézet GINOP-2.3.2-15-2016-00010 jelü „Földi energiaforrások hasznosításához kapcsolódó hatékonyság növelő mérnöki eljárások fejlesztése" projektjének részeként - a Széchenyi 2020 program keretében - az Európai Unió támogatásával, az Európai Strukturális és Beruházási Alapok társfinanszírozásával valósul meg.

Jelen tanulmányunk a szerzőknek a J. Molecular Liquids 276 (2019) 875-884 folyóiratban megjelent cikkének bővített változata

\section{Hivatkozások}

1. Dukhin, S.S., Zimmermann, R., Werner, C. Electrical Phenomena at Interfaces and Biointerfaces: Fundamentals and Applications in Nano-, Bio-, and Environmental Sciences, John Wiley \& Sons: New York, 2012.

2. Dukhin, S. Derjaguin, B. Electrokinetic Phenomena, in: Surface and Colloid Science (E. Matijevic, Ed.), Vol. 7. Wiley: New York- Toronto, 1974.

3. Dukhin, S.S. Adv. Colloid Interf. Sci. 1993,44, 1-134. https://doi.org/10.1016/0001-8686(93)80021-3

4. Bárány S. Adv. Colloid Interf. Sci.1998,75, 45-75. https://doi.org/10.1016/S0001-8686(97)00043-2

5. Lyklema J.Fundementals of Interface and Colloid Science, Academic Press, London, 1995.

6. Lyklema, J. Minor, M. Colloids Surf. A.1998,140, 33-41. https://doi.org/10.1016/S0927-7757(97)00266-5

7. Fridrichsberg D.A., Barkovskii V.Ya. Colloid J. of the USSR, 1964, 26, 722-728.

8. Baran A.A., Dudkina L.M., Soboleva N.M., Chechik O.S. Colloid J. of the USSR. 1981,43, 211-219.

9. Baran, A.A., Mitina, N.S., Platonov, B.E. Colloid J. of the USSR.1982,44, 964-969.

10. Hidalgo-Alvares R., Moleon J.A., Nieves F.J., Bijsterbosch B. J. Colloid Interf. Sci., 1992, 149, 23-26. https://doi.org/10.1016/0021-9797(92)90386-Z

11. Radeva, T., Dukhin, S.S., Shilov, V.N., Baran, A.A. Colloid J. of the USSR, 1982, 44, 234-238.

12. Leroy P., Tournassant C., Bernard O., Devau N., Azaroual M. J. Colloid Interf Sci., 2015, 451, 21-39. https://doi.org/10.1016/j.jcis.2015.03.047 


\section{Electrosurface properties of hydrophobic and hydrophilic suspensions: validity of the Hofmeister series. II. Electrical conductivity}

To obtain additional information about the electrical double layer (EDL) structure and mobility of ions within its limit (additionally to electrophoretic measurements described in section I)) studies of the electrical conductivity of suspensions have been performed. A short description of modern ideas on the surface conductivity of dispersed particles in electrolytes solution is given.

In electrolytes solution, the polarization of the EDL contributes to the conductivity of dispersions. Under action of an electric field, the particles polarize and acquire a dipole moment. The theory of surface conductivity gives the equation for the relative conductivity of suspension: $\mathrm{Kd} / \mathrm{Km}=1-1.5(1-3 \mathrm{Du} /(1+\mathrm{Du}))$, where $\mathrm{Kd}$ - is the conductivity of the dispersion, $\mathrm{Km}$ - that of the medium, $\mathrm{Du}=\mathrm{Ks}$ / $(\mathrm{aKm})$ is the so-called Du number, Ks-is the specific surface conductivity and $\mathrm{a}-$ is the radius of particles or flocs. The surface conductivity represents the excess conductivity of ions in the EDL compared to that in the bulk phase.

The Dukhin-Derjaguin relationship of the relative surface conductivity of suspensions $K d / K m$ ( $K d$ - conductivity of dispersion, $\mathrm{Km}$ - that of the medium) containing spherical particles vs. volume fraction of the solid $\mathrm{p}$ and the dimensionless $D u$ number (which characterizes the contribution of the EDL polarization to electrosurface phenomena) is given (Eq. 4). It has been shown that the relative electrical conductivity of polystyrene latex, zirconium dioxide, bentonite and laponite suspensions at fixed concentration of alkali metal chlorides, $C$, and given concentration of particles regularly decreased in the Hofmeister series from $\mathrm{Li}+$ to $\mathrm{Cs}+$.

In general case the specific surface conductivity includes contributions of counter-ion mobilities in the Stern layer and diffuse part of the EDL. The contribution of ions in the first layer is smaller than that of the diffuse part because of the high potential barrier for jumps of the ions and viscous resistance in the vicinity of the solid surface. So, the obtained data serve as an evidence of decreasing the surface conductivity as a result of increasing filling up the Stern layer in the mentioned sequence.

In accordance with electrophoretic measurements (see section I), it was shown that in Na-bentonite suspensions the $\mathrm{Kd} / \mathrm{Km}(\mathrm{p})$ plots for $\mathrm{K}+$ and $\mathrm{Rb}+$ run close to each other which testifies the increased affinity of $\mathrm{K}+$ ions to the mineral surface.

In $\mathrm{NaCl}$ and $\mathrm{KCl}$ solutions all three regimes of the $K d / K m(p)$ plots have been realized: at $C<5 \times 10-4-10-3 \mathrm{M}$ the superconducting regime $K d>K m$ with developed ionic atmosphere and substantial contribution of the surface conductivity to the conductivity of suspension, at higher $C$ values the role of surface conductivity was negligible.

Also it has been found that under our experimental conditions, in the region of the positive slopes of the $K d / K m(p)$ curves, the values of $\kappa a$ (here $\kappa$-is the reciprocal Debye length, a is the particles radius) were several units or several tens of unit, and the values of $D u$ number varied typically in a range of $0.06-1.7$ (for polystyrene 7.0). This means that at calculations of the $\zeta$-potential, the EDL polarization might, as a first approximation, be ignored. This circumstance gave us grounds to calculate the $\zeta$-potential from the data on the electrophoretic mobility of particles using the Smoluchowski equation (see section 1). The observed behaviour of the relative electrical conductivity of hydrophobic and hydrophilic suspensions evidenced the regular decrease of the contribution of the polarization of the EDL (surface conductivity) in the Hofmeister series from $\mathrm{Li}+$ to $\mathrm{Cs}+$. Overall the changes in both the $\zeta$-potential and electrical conductivity in Hofmeister series correlated with the differences in ionic radius, mobility, etc. These changes can be explained by differences in localization of the alkali ions in the diffuse and dense parts of the EDL 